\section{An unusual complication of a proximally migrated stent: liver capsule rupture}

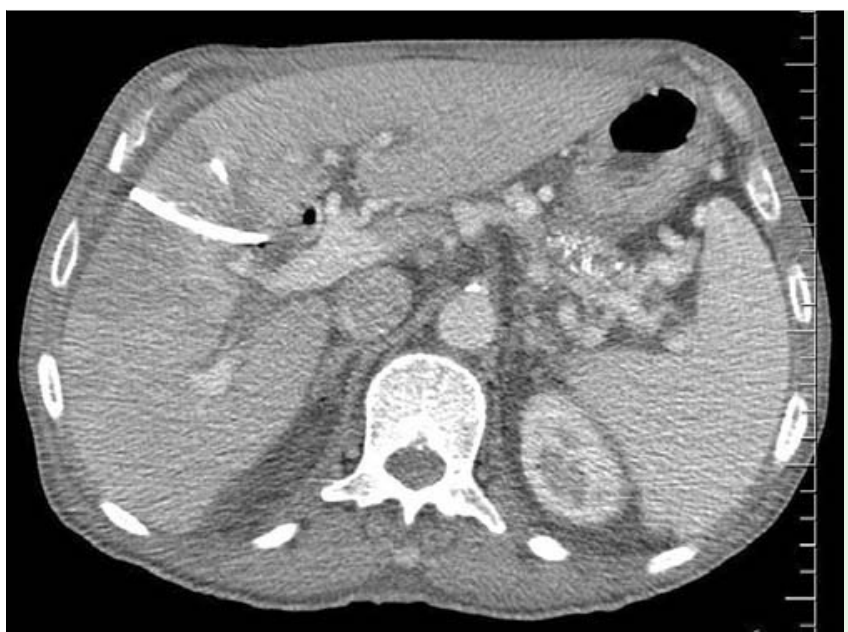

Fig. 1 Computed tomography shows a proximally migrated stent associated with rupture of the liver capsule in a 67 -year-old man with a medical history of chronic alcoholic pancreatitis and symptoms of abdominal pain, fatigue, and fever.
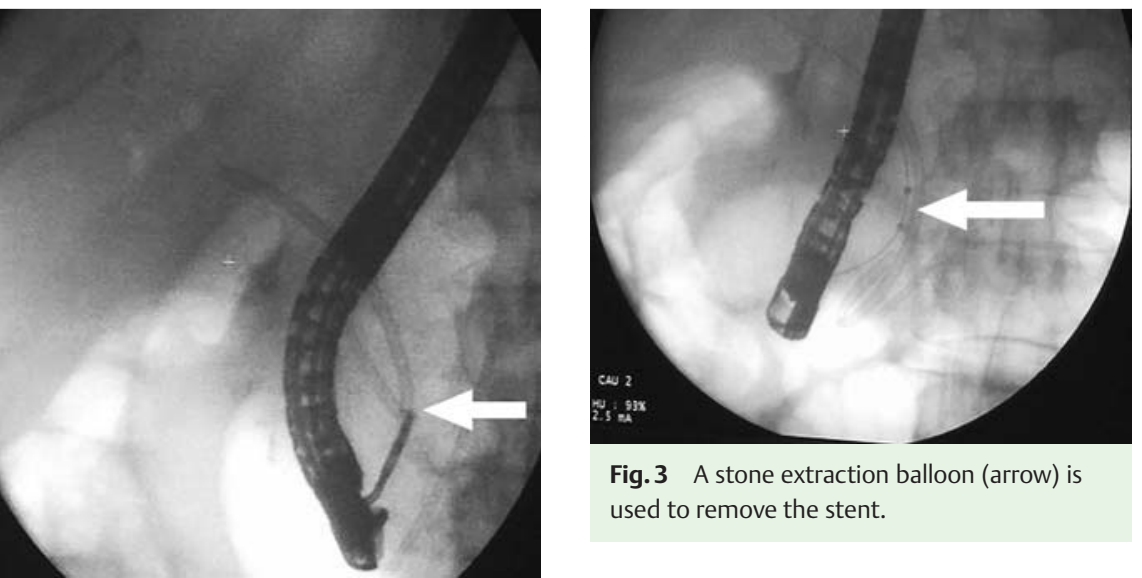

Fig. 3 A stone extraction balloon (arrow) is used to remove the stent.

Fig. 2 An alligator forceps (arrow) is used to withdraw the stent.

Plastic stents are widely used for the management of biliary strictures, biliary stones, and cholangitis. Well-known complications associated with biliary stents are occlusion and migration. The frequency of migration is reported as $5 \%$ to $10 \%$ [1]. Migration occurs predominantly distally; however, proximal migration may also be seen.

A 67-year-old man was admitted to our hospital with abdominal pain, fatigue, and fever. He had a medical history of chronic alcoholic pancreatitis, and a biliary stent had been placed in his common bile duct 1 year earlier for distal biliary stenosis associated with chronic pancreatitis. However, he had not undergone routine examinations during the year following stent placement. parameters were as follows: hemoglobin level, 9.1 g/dL (normal 12-16); white blood cell count, $15100 / \mu \mathrm{L}$ (normal 3900-11700); C-reactive protein level, $176 \mathrm{mg} / \mathrm{L}$ (normal 0 - 5); erythrocyte sedimentation rate, $93 \mathrm{~mm} / \mathrm{h}$ (normal 0-20); and $\gamma$-glutamyltransferase (GGT) level, 147 U/L (normal 0 - 50). Computed tomography revealed a proximally migrated biliary plastic stent, which was associated with rupture of the liver capsule and an abscess in the right lobe ( $\bullet$ Fig. 1).

At first, the abscess was drained percutaneously. Subsequently, endoscopic retrograde cholangiopancreatography (ERCP) was performed to remove the proximally migrated stent. The stent was held and withdrawn gently with an alligator forceps ( $\bullet$ Fig. 2). However, the stent was folded over, so that it could not be removed with the forceps through the distal biliary stricture. Instead, the stent was removed with a stone extraction balloon ( $\bullet$ Fig.3). The distal part of the stent was held and extracted with the alligator forceps within the lumen of the duodenum. During follow-up, the patient's fever and leukocytosis were seen to regress.

Biliary stent migration may cause serious complications [2]. Proximal migration of a stent associated with abscess and rupture of the hepatic capsule is a rare condition. Several techniques have been described in the literature for the extraction of proximally migrated stents. Forceps, Dormia baskets, and balloons are widely used to hold and remove stents. In the case of our patient, stent removal with a forceps and a stone extraction balloon was successful, and appropriate percutaneous drainage was performed as well.

Endoscopy_UCTN_Code_CPL_1AK_2AD

Competing interests: None

\section{Bülent Ödemis, Muhammet Yener Akpinar, Erkin Oztas, Mustafa Kaplan, Ufuk Baris Kuzu, Ertugrul Kayacetin}

Department of Gastroenterology, Türkiye Yüksek ihtisas Training and Research Hospital, Ankara, Turkey

\section{References}

1 Bagul A, Pollard C, Dennison AR et al. A review of problems following insertion of biliary stents illustrated by an unusual complication. Ann R Coll Surg Engl 2010; 92: 27 31

2 Mady RF, Niaz OS, Assal MM. Migrated biliary stent causing perforation of sigmoid colon and pelvic abscess. BMJ Case Rep 2015 Apr 13. 2015
Bibliography

DOI http://dx.doi.org/

10.1055/s-0035-1569654

Endoscopy 2015; 47: E618

(c) Georg Thieme Verlag KG

Stuttgart · New York

ISSN 0013-726X

\section{Corresponding author}

\section{Muhammet Yener Akpinar, MD}

Department of Gastroenterology

Türkiye Yüksek Ihtisas Training and Research

Hospital

Kızılay Street

Ankara

Turkey

Fax: +90-312-3124120

muhammet.yener@gmail.com
Sihhiye, 06100 